\title{
Therapeutic Anticoagulation in Non-Critically III Patients with Covid-19
}

The ATTACC, ACTIV-4a, and REMAP-CAP Investigators

\section{Author and Group Information}

The members of the writing committee appear at the end of the main text and the full list of investigators and collaborators appears in the Supplementary Appendix.

\section{Keywords:}

anticoagulation, heparin, low molecular weight heparin, Covid-19, adaptive platform trial

Word count: $2694 / 2700$

\section{Corresponding authors:}

Ryan Zarychanski, MD, MSc

Sections of Hematology/Oncology and Critical Care

University of Manitoba

Winnipeg, Manitoba, Canada R3E 0V9

Email: rzarychanski@cancercare.mb.ca

and

Judith S. Hochman, MD, MA

New York University Grossman School of Medicine

New York University Langone Health

530 First Ave., Skirball 9R

New York, NY, USA 10016

Email: judith.hochman@nyumc.org 
medRxiv preprint doi: https://doi.org/10.1101/2021.05.13.21256846; this version posted May 17, 2021. The copyright holder for this preprint (which was not certified by peer review) is the author/funder, who has granted medRxiv a license to display the preprint in perpetuity.

\section{Abstract}

\section{Background}

Thrombo-inflammation may contribute to morbidity and mortality in Covid-19. We hypothesized that therapeutic-dose anticoagulation may improve outcomes in non-critically ill patients hospitalized for Covid-19.

\section{Methods}

In an open-label adaptive multiplatform randomized controlled trial, non-critically ill patients hospitalized for Covid-19, defined by the absence of critical care-level organ support at enrollment, were randomized to a pragmatic strategy of therapeutic-dose anticoagulation with heparin or usual care pharmacological thromboprophylaxis. The primary outcome combined survival to hospital discharge and days free of organ support through 21 days, which was evaluated with Bayesian statistical models according to baseline D-dimer.

Results

The trial was stopped when prespecified criteria for superiority were met for therapeutic-dose anticoagulation in groups defined by high ( 22 -fold elevated) and low (<2-fold elevated) Ddimer. Among 2219 participants in the final analysis, the probability that therapeutic anticoagulation increased organ support-free days compared to thromboprophylaxis was $99.0 \%$ (adjusted odds ratio 1.29, 95\% credible interval 1.04 to 1.61). The adjusted absolute increase in survival to hospital discharge without organ support with therapeutic-dose anticoagulation was $4.6 \%$ (95\% credible interval 0.7 to 8.1 ). In the primary adaptive stopping groups, the final probabilities of superiority for therapeutic anticoagulation were $97.3 \%$ in the high D-dimer group and $92.9 \%$ in the low D-dimer group. Major bleeding occurred in $1.9 \%$ and $0.9 \%$ of participants randomized to therapeutic anticoagulation and thromboprophylaxis, respectively.

\section{Conclusions}

In non-critically ill patients with Covid-19, an initial strategy of therapeutic-dose anticoagulation with heparin increases the probability of survival to hospital discharge with reduced use of organ support.

Trial registration numbers: NCT02735707, NCT04505774, NCT04359277, NCT04372589 
medRxiv preprint doi: https://doi.org/10.1101/2021.05.13.21256846; this version posted May 17, 2021. The copyright holder for this preprint (which was not certified by peer review) is the author/funder, who has granted medRxiv a license to display the preprint in perpetuity.

\section{Background}

The clinical course of Covid-19 is characterized by an initial period of mild to moderate symptoms, followed by progressive respiratory failure and requirement for intensive care unit (ICU)-level organ support or death in some patients. ${ }^{1,2}$ The majority of patients requiring hospitalization are moderately ill, not initially requiring ICU-level organ support. ${ }^{3-5}$ Limited therapies are available to prevent clinical progression to ICU-level organ support and death among moderately ill hospitalized patients.

Patients with Covid-19 have a notable incidence of macro- and microvascular thrombosis and inflammation in association with poor clinical outcomes. ${ }^{6,7}$ Given the anti-thrombotic, antiinflammatory, and possible anti-viral properties of heparins, ${ }^{8-10}$ it has been hypothesized that anticoagulation with heparin administered at doses higher than conventionally used for venous thromboprophylaxis may improve outcomes. ${ }^{11}$ Further, elevated D-dimer is associated with vascular thrombosis and poor clinical outcomes, ${ }^{6,12}$ and thus some have advocated using Ddimer to guide anticoagulant dosing in patients with Covid-19. In the absence of data from randomized trials, clinical guideline recommendations ${ }^{13}$ and practice ${ }^{14}$ vary widely.

To determine whether an initial strategy of therapeutic-dose anticoagulation with heparin improves survival to hospital discharge with reduced use of ICU-level organ support in hospitalized, non-critically ill patients with Covid-19, we conducted an international, adaptive, multiplatform randomized controlled trial (mpRCT). 
medRxiv preprint doi: https://doi.org/10.1101/2021.05.13.21256846; this version posted May 17, 2021. The copyright holder for this preprint (which was not certified by peer review) is the author/funder, who has granted medRxiv a license to display the preprint in perpetuity.

\section{Methods}

\section{Trial Design and Oversight}

To accelerate evidence generation, three adaptive randomized controlled trial protocols evaluating therapeutic-dose anticoagulation with heparin in patients hospitalized for Covid-19 were integrated into a single $\mathrm{mpRCT}$. Alignment of eligibility criteria, interventions, outcome measures, and data collection was prospectively undertaken. A joint analysis plan was implemented involving periodic evaluation of statistical stopping criteria (Protocol Appendix). Independent data and safety monitoring boards (DSMBs) oversaw the platforms using a collaborative cross-platform DSMB interaction plan. The participating platforms were Antithrombotic Therapy To Ameliorate Complications of Covid-19 (ATTACC; NCT04372589), ${ }^{15}$ Accelerating Covid-19 Therapeutic Interventions and Vaccines-4 Antithrombotics Inpatient platform trial (ACTIV-4a, NCT04505774; which included a vanguard/pilot, NCT04359277), and Randomized, Embedded, Multifactorial Adaptive Platform Trial for Community-Acquired Pneumonia (REMAP-CAP, NCT02735707). ${ }^{16}$ The trial was approved by relevant ethics committees and conducted in accordance with Good Clinical Practice guidelines and the Declaration of Helsinki. Written or verbal informed consent, in accordance with regional regulations, was obtained from all participants or their surrogates. The trial was supported by multiple international funding organizations which had no role in the design, analysis, or reporting of the trial results, apart from the ACTIV-4a protocol which received input on design from the National Institutes of Health professional staff and peer reviewers. 
medRxiv preprint doi: https://doi.org/10.1101/2021.05.13.21256846; this version posted May 17, 2021. The copyright holder for this preprint (which was not certified by peer review) is the author/funder, who has granted medRxiv a license to display the preprint in perpetuity.

All rights reserved. No reuse allowed without permission.

\section{Participants}

The mpRCT enrolled patients hospitalized for Covid-19. The investigators hypothesized that the benefits and risks of therapeutic-dose anticoagulation with heparin may vary according to disease severity. As such, the design prospectively stratified participants into severe (ICU-level of care; critically ill) and moderate (hospitalized; non-critically ill) disease severity states at enrollment. Moderate disease severity was defined as hospitalization for Covid-19 without the requirement for ICU-level of care. ICU-level of care was defined by use of respiratory or cardiovascular organ support (high flow nasal oxygen, non-invasive or invasive mechanical ventilation, vasopressors, or inotropes) in an ICU. In ACTIV-4a, where definitions of an ICU were thought challenging to operationalize during the pandemic, receipt of organ support, irrespective of hospital setting, was used to define ICU-level of care. Participants admitted to an ICU but without the receipt of qualifying organ support were considered moderately ill. Participants with moderate disease severity were further stratified by their baseline D-dimer: high D-dimer group (D-dimer $\geq 2$ times the upper limit of normal per local assay); low D-dimer group (D-dimer <2 times the upper limit of normal per local assay); or unknown D-dimer group. Patients were ineligible for enrollment beyond 72 hours after hospital admission for Covid-19 or in-hospital SARS-CoV-2 confirmation (ATTACC, ACTIV-4a) or after 14 days following admission (REMAP-CAP). In addition, patients were excluded if discharge was expected within 72 hours, or if they had a clinical indication for therapeutic anticoagulation, high risk for bleeding, required dual antiplatelet therapy, or had a history of heparin allergy including heparin-induced thrombocytopenia (HIT). Detailed exclusion criteria are provided in the

\section{Protocol Appendix.}


medRxiv preprint doi: https://doi.org/10.1101/2021.05.13.21256846; this version posted May 17, 2021. The copyright holder for this preprint (which was not certified by peer review) is the author/funder, who has granted medRxiv a license to display the preprint in perpetuity.

\section{Randomization}

Using central web-based systems, participants were randomized to receive an initial pragmatic strategy of therapeutic-dose anticoagulation with heparin or usual care pharmacological thromboprophylaxis in an open label fashion. Therapeutic-dose low molecular weight or unfractionated heparin was administered according to local protocols used for the treatment of acute venous thromboembolism for up to 14 days or until recovery (defined as hospital discharge, or liberation from supplemental oxygen for $\geq 24$ hours). Thromboprophylaxis was provided according to local practice.

A subset of REMAP-CAP participants were randomized in other platform domains, including an antiplatelet domain. Treatment assignments were initially randomized in a 1:1 ratio. The ATTACC and REMAP-CAP designs specified the possibility for response-adaptive randomization, whereby blinded randomization allocation ratios could be modified during the trial based on adaptive analyses to favor allocation of participants to the treatment arm demonstrating greater benefit. In participants with moderate severity Covid-19, responseadaptive randomization was implemented for ATTACC participants on December 15, 2020.

\section{Outcome Measures}

The primary outcome was organ support-free days, an ordinal outcome composed of survival to hospital discharge and, among survivors, the number of days free of ICU-level organ support through day 21. Any death during the index hospitalization through 90 days was assigned -1 . This endpoint thus reflects both utilization of critical care therapies and survival. Higher values for organ support-free days indicate better outcomes. 
medRxiv preprint doi: https://doi.org/10.1101/2021.05.13.21256846; this version posted May 17, 2021. The copyright holder for this preprint (which was not certified by peer review) is the author/funder, who has granted medRxiv a license to display the preprint in perpetuity.

All rights reserved. No reuse allowed without permission.

Pre-specified secondary efficacy outcomes included survival, survival without receipt of organ support, survival without receipt of invasive mechanical ventilation, mechanical respiratory support-free days (days free of invasive or non-invasive mechanical ventilation), time-to-hospital discharge, survival without symptomatic major thrombotic events (a composite of freedom from myocardial infarction, pulmonary embolism, ischemic stroke, systemic arterial embolism, and in-hospital death), and survival without any macrovascular thrombotic event (the components of major thrombotic events and symptomatic deep venous thrombosis) (Supplementary Appendix). Pre-specified secondary safety outcomes assessed during the treatment period were major bleeding, as defined by the International Society of Thrombosis and Haemostasis, ${ }^{17}$ and laboratory-confirmed HIT. All reported bleeding and thrombotic events were adjudicated in a blinded fashion by clinical endpoints committees using consensus definitions (Supplementary Appendix).

\section{Statistical Analysis}

The primary analysis was a Bayesian cumulative logistic model that calculated the posterior probability distribution for the proportional odds ratio for therapeutic-dose anticoagulation compared with thromboprophylaxis on organ support-free days in participants with microbiologically confirmed SARS-CoV-2 infection. The primary model incorporated weaklyinformative Dirichlet prior distributions for organ support-free days proportions, and was adjusted for age, sex, site, D-dimer group, and enrollment time period. The model was fit using a Markov Chain Monte Carlo algorithm with 100,000 samples from the joint posterior distribution, allowing calculation of the posterior distributions for the proportional odds ratios, 
medRxiv preprint doi: https://doi.org/10.1101/2021.05.13.21256846; this version posted May 17, 2021. The copyright holder for this preprint (which was not certified by peer review) is the author/funder, who has granted medRxiv a license to display the preprint in perpetuity. All rights reserved. No reuse allowed without permission.

including medians and $95 \%$ credible intervals (Crls), and the posterior probabilities of superiority and futility for therapeutic-dose anticoagulation compared with usual care thromboprophylaxis. In this report, odds ratios $>1.0$ favor therapeutic-dose anticoagulation.

The primary model estimated treatment effects for each of the disease severity-defined groups (severe and moderate, the latter stratified by baseline D-dimer), utilizing a Bayesian hierarchical approach. The treatment effects of anticoagulation for the groups were nested in a hierarchical prior distribution centered on an overall intervention effect estimated with a neutral prior, but distinct group-specific effects were estimated. When consistent effects were observed for the groups, the posterior distribution for each intervention group effect is shrunk towards the overall estimate (dynamic borrowing). ${ }^{18}$ The stopping criteria for treatment superiority ( $>99 \%$ probability of odds ratio $>1.0$ ) and futility $(<5 \%$ probability of odds ratio $>1.2)$ were evaluated monthly by an independent statistical analysis committee and could be reached within the low and/or high D-dimer groups at each adaptive analysis. Sensitivity analyses of the primary model assuming independent treatment effects (without dynamic borrowing) in each D-dimer group are also reported. Additionally, analyses are presented from the overall moderate severity cohort assuming a single treatment effect irrespective of D-dimer.

Subgroup analyses assessed whether treatment effect varied according to age, sex, baseline respiratory support, and thromboprophylaxis dosing. Protocol adherence was defined by the anticoagulant dose equivalent administered within the first $24-48$ hours following randomization (Supplementary Appendix for consensus dosing categories). Doses categorized as therapeutic and subtherapeutic heparin qualified as adherent in the therapeutic-dose anticoagulation arm, and low- and intermediate prophylactic-dose anticoagulants qualified as 
medRxiv preprint doi: https://doi.org/10.1101/2021.05.13.21256846; this version posted May 17, 2021. The copyright holder for this preprint (which was not certified by peer review) is the author/funder, who has granted medRxiv a license to display the preprint in perpetuity.

All rights reserved. No reuse allowed without permission.

adherent in the thromboprophylaxis arm. The analysis of this dataset was pre-specified in a statistical analysis plan (Protocol Appendix).

\section{Results}

The first participant was randomized on April 21, 2020. On January 22, 2021, enrollment was discontinued on advice from the DSMBs after planned adaptive analyses of 1398 moderate severity participants demonstrated that the pre-specified stopping criteria for superiority of therapeutic-dose anticoagulation had been reached in both the high and low D-dimer groups (Supplementary Appendix Table S1). By that time, 2245 moderate severity participants had been randomized. The primary analysis population consisted of 2219 participants with SARSCoV-2 confirmation for whom the primary outcome was known (Figure 1). Parallel enrollment of patients with severe Covid-19 ran through December 19, 2020; these results are reported separately. ${ }^{19}$

\section{Participants}

Baseline characteristics were similar between treatment arms (Table 1), including within each D-dimer group (Supplementary Appendix Table S2). Participants in the high D-dimer and unknown D-dimer groups were generally older with a higher prevalence of comorbid diseases compared to those in the low D-dimer group. Concomitant therapies at enrollment included antiplatelet agents (12\%), corticosteroids (62\%), and remdesivir (36\%).

Adherence to protocol-assigned anticoagulation dose on the day following randomization was $88.3 \%$ in the therapeutic-dose anticoagulation arm and $98.3 \%$ in the thromboprophylaxis 
medRxiv preprint doi: https://doi.org/10.1101/2021.05.13.21256846; this version posted May 17, 2021. The copyright holder for this preprint (which was not certified by peer review) is the author/funder, who has granted medRxiv a license to display the preprint in perpetuity. All rights reserved. No reuse allowed without permission.

arm (Supplementary Appendix Table 3). Among participants randomized to therapeutic-dose heparin, $94.7 \%(1035 / 1093)$ received a low molecular weight heparin, most commonly enoxaparin. Among participants allocated to usual care thromboprophylaxis, $71.7 \%$ (613/855) received low-dose and $26.5 \%$ (227/855) received intermediate-dose thromboprophylaxis.

\section{Primary Outcome}

Among 2219 participants in the overall moderate severity cohort, the posterior probability that therapeutic-dose anticoagulation increased organ support-free days compared to usual care thromboprophylaxis was $99.0 \%$ (median adjusted odds ratio $1.29,95 \% \mathrm{Crl} 1.04$ to 1.61 ) (Figure 2 and Figure 3). The proportion of participants in the thromboprophylaxis arm surviving to hospital discharge without receipt of organ support during the first 21 days (control event frequency) was $76.4 \%$ (247/1048). The median adjusted absolute improvement in this proportion with therapeutic-dose anticoagulation was $4.6 \%$ (95\% Crl 0.7 to 8.1 ). In the primary adaptive analysis groups, the final posterior probability for superiority of therapeutic-dose anticoagulation compared with usual care thromboprophylaxis was $97.3 \%$ (adjusted odds ratio $1.31,95 \% \mathrm{Crl} 1.00$ to 1.76$)$ in the high D-dimer group $(n=630)$ and $92.9 \%$ (adjusted odds ratio 1.22, $95 \% \mathrm{Crl} 0.93$ to 1.57 ) in the low D-dimer group ( $\mathrm{n}=1075)$ (Figure 3 and Supplementary Appendix Figure S1). The posterior probability of superiority of therapeutic-dose anticoagulation in the unknown D-dimer group $(n=514)$ was $97.3 \%$ (adjusted odds ratio 1.32, 95\% Crl 1.00 to 1.86). The results were consistent in sensitivity analyses (Supplementary

\section{Appendix Table S4).}


medRxiv preprint doi: https://doi.org/10.1101/2021.05.13.21256846; this version posted May 17, 2021. The copyright holder for this preprint (which was not certified by peer review) is the author/funder, who has granted medRxiv a license to display the preprint in perpetuity.

All rights reserved. No reuse allowed without permission.

In the overall moderate severity cohort, the treatment effect did not vary meaningfully by age, respiratory support at enrollment, or thromboprophylaxis dosing. There was a $95.5 \%$ probability that the odds ratio associated with therapeutic-dose anticoagulation was higher in men compared to women (Supplementary Appendix Figure S2).

\section{Secondary Outcomes}

Secondary outcomes are shown in Figure 3, Figure 4, and Supplementary Appendix Table S5.

In the overall moderate severity cohort, the posterior probabilities that therapeutic-dose anticoagulation increased survival without organ support or survival without invasive mechanical ventilation through 28 days were $99.1 \%$ and $92.2 \%$, respectively. The posterior probability that therapeutic-dose anticoagulation improved survival to hospital discharge compared with thromboprophylaxis was $87.1 \%$ (median adjusted odds ratio $1.21,95 \% \mathrm{Crl} 0.87$ to 1.68 ; median adjusted absolute improvement $1.3 \%, 95 \% \mathrm{Crl}-1.1$ to $3.2 \%)$.

A major thrombotic event or death in-hospital occurred in $8.0 \%(94 / 1180)$ of participants randomized to therapeutic-dose anticoagulation and 9.9\% (104/1046) of participants randomized to thromboprophylaxis (Figure 3 and Supplementary Appendix Tables S5 and S6). The composite secondary thrombosis outcome including deep vein thrombosis is reported in Supplementary Appendix Table S5. Major bleeding occurred in 1.9\% (22/1180) of participants randomized to therapeutic-dose anticoagulation and 0.9\% (9/1047) of participants randomized to thromboprophylaxis (Supplementary Appendix Table S7). Fatal bleeding occurred in three participants randomized to therapeutic-dose anticoagulation and one participant randomized 
medRxiv preprint doi: https://doi.org/10.1101/2021.05.13.21256846; this version posted May 17, 2021. The copyright holder for this preprint (which was not certified by peer review) is the author/funder, who has granted medRxiv a license to display the preprint in perpetuity.

All rights reserved. No reuse allowed without permission.

to thromboprophylaxis. No episodes of intracranial bleeding or confirmed HIT occurred during the treatment window.

\section{Discussion}

In this randomized trial report of non-critically ill patients hospitalized for Covid-19,

therapeutic-dose anticoagulation with heparin increased the probability of surviving to hospital discharge with reduced need for ICU-level organ support, including invasive and non-invasive mechanical ventilation. Therapeutic-dose anticoagulation with heparin was beneficial irrespective of baseline D-dimer. Major bleeding occurred infrequently.

Several non-randomized cohort studies have observed favorable associations between anticoagulant use and survival from Covid-19, although these studies are at risk of bias. ${ }^{20-22}$ Because SARS-CoV-2 infection incites a dysregulated inflammatory response that may cascade to activation of coagulation and widespread thrombin generation, ${ }^{23}$ potentially contributing to organ failure, ${ }^{24-26}$ heparins may reduce the requirement for organ support by limiting thromboinflammation through anti-thrombotic, anti-inflammatory, and potentially anti-viral mechanisms. ${ }^{8-10,27}$ The results from this $\mathrm{mpRCT}$ show that empiric therapeutic-dose anticoagulation with heparin provided to patients hospitalized prior to the receipt of ICU-level organ support improved outcomes.

In contrast, in a parallel enrolling group of the $\mathrm{mpRCT}$ comprised of critically-ill patients (receiving ICU-level of care at enrollment), empiric therapeutic-dose anticoagulation was not beneficial. ${ }^{19}$ In a separate randomized trial in critically-ill patients with Covid-19, intermediatedose heparin was likewise not beneficial. ${ }^{28}$ Differential treatment effects based on illness 
medRxiv preprint doi: https://doi.org/10.1101/2021.05.13.21256846; this version posted May 17, 2021. The copyright holder for this preprint (which was not certified by peer review) is the author/funder, who has granted medRxiv a license to display the preprint in perpetuity. All rights reserved. No reuse allowed without permission.

severity and the time course of SARS-CoV-2 infection have been reported in randomized trials of other Covid-19 therapies. ${ }^{29-31}$ It is possible that therapeutic-dose heparin is unable to influence the thrombo-inflammatory cascade and organ injury in patients with advanced disease and its sequale. ${ }^{32-34}$ Among moderately-ill participants in this $\mathrm{mpRCT}$, those in the high D-dimer group were at increased risk for mortality and receipt of organ support compared with those in the low D-dimer group and, accordingly, adjusted absolute treatment benefits were more apparent. Participants in the high D-dimer group were generally older with a higher prevalence of comorbid diseases.

Strengths of our trial design include elements incorporated to speed evidence generation. First, we adopted a novel prospective mpRCT design, whereby three collaborating platforms developed and administered harmonized trial protocols across complementary global networks of sites to increase efficiency and reliability of evidence generation. Second, the trial employed an adaptive Bayesian design which accounted for uncertainties in the pandemic. This approach allowed for trial conclusions to be reached simultaneously or sequentially in groups defined by illness severity and D-dimer through periodic adaptive analyses. Dynamic borrowing was incorporated to enable the trial to reach conclusions more quickly across the stopping groups where treatment effects were similar, and to mitigate the influence of outlying treatment effects by shrinking similar treatment estimates together. Response-adaptive randomization allowed randomization probabilities to be modified as the trial acquired knowledge about treatment effects. Response-adaptive randomization may lead to imbalances in baseline covariates between treatment arms over time, and as such the primary models of treatment effect are necessarily adjusted for age, sex, site, D-dimer group, and time. Given the importance 
medRxiv preprint doi: https://doi.org/10.1101/2021.05.13.21256846; this version posted May 17, 2021. The copyright holder for this preprint (which was not certified by peer review) is the author/funder, who has granted medRxiv a license to display the preprint in perpetuity.

All rights reserved. No reuse allowed without permission.

of accounting for these factors under this design, absolute risk reductions based on adjusted treatment effects and observed control event rates are presented. The adjusted absolute improvement in outcomes presented is a median; patients at higher baseline risk, including older age, male sex, and higher baseline D-dimer may derive greater absolute benefit.

Although the open-label design of the $\mathrm{mpRCT}$ represents a potential limitation, the primary outcome involving survival and receipt of organ support was selected to minimize bias and to function across a spectrum of illness severity. The potential for ascertainment bias cannot be excluded for the secondary outcomes of major bleeding or thrombosis. This, along with the absence of protocolized screening for venous thrombosis, exclusion of patients at increased bleeding risk, and changing disease epidemiology over time may have contributed to lower thrombotic event rates than have been previously reported. ${ }^{35}$ The treatment effect was attenuated in the final analysis relative to the adaptive stopping results; nevertheless, a high probability of benefit persisted in all D-dimer groups.

In conclusion, in hospitalized, non-critically ill patients with Covid-19, an initial strategy of therapeutic-dose anticoagulation with heparin improves organ support-free days. Therapeuticdose anticoagulation increases the probability of survival to hospital discharge with reduced use of critical care-level organ support. 
medRxiv preprint doi: https://doi.org/10.1101/2021.05.13.21256846; this version posted May 17, 2021. The copyright holder for this preprint (which was not certified by peer review) is the author/funder, who has granted medRxiv a license to display the preprint in perpetuity. All rights reserved. No reuse allowed without permission.

\section{Acknowledgements}

We are grateful for the support of the patients and their families who participated in this trial.

We thank those who served on the Data Safety and Monitoring Boards of each platform; we gratefully acknowledge the support of multiple funding organizations for the participating platforms (Supplementary Appendix). 
medRxiv preprint doi: https://doi.org/10.1101/2021.05.13.21256846; this version posted May 17, 2021. The copyright holder for this preprint (which was not certified by peer review) is the author/funder, who has granted medRxiv a license to display the preprint in perpetuity.

All rights reserved. No reuse allowed without permission.

\section{References}

1. Zhou F, Yu T, Du R, et al. Clinical course and risk factors for mortality of adult inpatients with COVID-19 in Wuhan, China: a retrospective cohort study. Lancet 2020;395(10229):1054-1062.

2. Mody A, Lyons PG, Guillamet CV, et al. The Clinical Course of COVID-19 Disease in a US Hospital System: a Multi-state Analysis. American Journal of Epidemiology 2021;190(4):539-552.

3. Richardson S, Hirsch JS, Narasimhan M, et al. Presenting Characteristics, Comorbidities, and Outcomes Among 5700 Patients Hospitalized With COVID-19 in the New York City Area. JAMA 2020;323(20):2052-2059.

4. Lewnard JA, Liu VX, Jackson ML, et al. Incidence, clinical outcomes, and transmission dynamics of severe coronavirus disease 2019 in California and Washington: prospective cohort study. BMJ 2020;369:m1923.

5. Garibaldi BT, Fiksel J, Muschelli J, et al. Patient Trajectories Among Persons Hospitalized for COVID-19 : A Cohort Study. Annals of Internal Medicine 2021;174(1):33-41.

6. Bilaloglu S, Aphinyanaphongs $Y$, Jones S, Iturrate E, Hochman J, Berger JS. Thrombosis in Hospitalized Patients With COVID-19 in a New York City Health System. JAMA 2020;324(8):799-801.

7. Godoy LC, Goligher EC, Lawler PR, Slutsky AS, Zarychanski R. Anticipating and managing coagulopathy and thrombotic manifestations of severe COVID-19. CMAJ : Canadian Medical Association Journal 2020 192(40):E1156-E1161.

8. Clausen TM, Sandoval DR, Spliid CB, et al. SARS-CoV-2 Infection Depends on Cellular Heparan Sulfate and ACE2. Cell 2020;183(4):1043-1057.

9. Buijsers B, Yanginlar C, Maciej-Hulme ML, de Mast Q, van der Vlag J. Beneficial nonanticoagulant mechanisms underlying heparin treatment of COVID-19 patients. EBioMedicine 2020;59:102969.

10. Mycroft-West CJ, Su D, Pagani I, et al. Heparin Inhibits Cellular Invasion by SARS-CoV-2: Structural Dependence of the Interaction of the Spike S1 Receptor-Binding Domain with Heparin. Thrombosis and haemostasis 2020;120(12):1700-1715.

11. Chowdhury JF, Moores LK, Connors JM. Anticoagulation in Hospitalized Patients with Covid-19. The New England Journal of Medicine 2020;383(17):1675-1678.

12. Short SAP, Gupta S, Brenner SK, et al. D-dimer and Death in Critically III Patients With Coronavirus Disease 2019. Critical Care Medicine 2021;49(5):e500-e511.

13. Flaczyk A, Rosovsky RP, Reed CT, Bankhead-Kendall BK, Bittner EA, Chang MG. Comparison of published guidelines for management of coagulopathy and thrombosis in critically ill patients with COVID 19: implications for clinical practice and future investigations. Critical Care 2020;24(1):559.

14. Rosovsky RP, Sanfilippo KM, Wang TF, et al. Anticoagulation Practice Patterns in COVID19: A Global Survey. Research and Practice in Thrombosis and Haemostasis 2020; 4(6):969-983.

15. Houston BL, Lawler PR, Goligher EC, et al. Anti-Thrombotic Therapy to Ameliorate Complications of COVID-19 (ATTACC): Study design and methodology for an international, adaptive Bayesian randomized controlled trial. Clin Trials 2020;17(5):491500. 
medRxiv preprint doi: https://doi.org/10.1101/2021.05.13.21256846; this version posted May 17, 2021. The copyright holder for this preprint (which was not certified by peer review) is the author/funder, who has granted medRxiv a license to display the preprint in perpetuity.

All rights reserved. No reuse allowed without permission.

16. Angus DC, Berry S, Lewis RJ, et al. The REMAP-CAP (Randomized Embedded Multifactorial Adaptive Platform for Community-acquired Pneumonia) Study. Rationale and Design. Ann Am Thorac Soc 2020;17(7):879-891.

17. Schulman S, Kearon C, Subcommittee on Control of Anticoagulation of the S, Standardization Committee of the International Society on T, Haemostasis. Definition of major bleeding in clinical investigations of antihemostatic medicinal products in nonsurgical patients. J Thromb Haemost 2005;3(4):692-4.

18. McGlothlin AE, Viele K. Bayesian Hierarchical Models. JAMA 2018;320(22):2365-2366.

19. https://www.medrxiv.org/content/10.1101/2021.03.10.21252749v1.full.

20. Nadkarni GN, Lala A, Bagiella E, et al. Anticoagulation, Bleeding, Mortality, and Pathology in Hospitalized Patients With COVID-19. J Am Coll Cardiol 2020;76(16):18151826.

21. Ionescu F, Jaiyesimi I, Petrescu I, et al. Association of anticoagulation dose and survival in hospitalized COVID-19 patients: A retrospective propensity score-weighted analysis. Eur J Haematol 2021;106(2):165-174.

22. Frohlich $\mathrm{GM}$, Jeschke $\mathrm{E}$, Eichler $\mathrm{U}$, et al. Impact of oral anticoagulation on clinical outcomes of COVID-19: a nationwide cohort study of hospitalized patients in Germany. Clinical Research in Cardiology 2021;Jan 8:1-10.

23. Connors JM, Levy JH. COVID-19 and its implications for thrombosis and anticoagulation. Blood 2020;135(23):2033-2040.

24. Ackermann M, Verleden SE, Kuehnel M, et al. Pulmonary Vascular Endothelialitis, Thrombosis, and Angiogenesis in Covid-19. The New England Journal of Medicine 2020;383(2):120-128.

25. Hanley B, Naresh KN, Roufosse C, et al. Histopathological findings and viral tropism in UK patients with severe fatal COVID-19: a post-mortem study. The Lancet Microbe 2020;1(6):e245-e253.

26. Rapkiewicz AV, Mai X, Carsons SE, et al. Megakaryocytes and platelet-fibrin thrombi characterize multi-organ thrombosis at autopsy in COVID-19: A case series. EClinicalMedicine 2020;24:100434.

27. Liu J, Li J, Arnold K, Pawlinski R, Key NS. Using heparin molecules to manage COVID2019. Research and practice in thrombosis and haemostasis 2020;4(4):518-523.

28. Sadeghipour P, Talasaz AH, Rashidi F, et al. Effect of Intermediate-Dose vs StandardDose Prophylactic Anticoagulation on Thrombotic Events, Extracorporeal Membrane Oxygenation Treatment, or Mortality Among Patients With COVID-19 Admitted to the Intensive Care Unit: The INSPIRATION Randomized Clinical Trial. JAMA 2021;325(16):1620-1630.

29. Horby P, Lim WS, Emberson JR, et al. Dexamethasone in Hospitalized Patients with Covid-19. The New England Journal of Medicine 2021;384(8):693-704.

30. Libster R, Perez Marc G, Wappner D, et al. Early High-Titer Plasma Therapy to Prevent Severe Covid-19 in Older Adults. The New England Journal of Medicine 2021;384(7):610618.

31. Beigel JH, Tomashek KM, Dodd LE, et al. Remdesivir for the Treatment of Covid-19 - Final Report. The New England Journal of Medicine 2020;383(19):1813-1826. 
medRxiv preprint doi: https://doi.org/10.1101/2021.05.13.21256846; this version posted May 17, 2021. The copyright holder for this preprint

(which was not certified by peer review) is the author/funder, who has granted medRxiv a license to display the preprint in perpetuity.

All rights reserved. No reuse allowed without permission.

32. Xue $\mathrm{M}$, Zeng $\mathrm{Y}, \mathrm{Qu} \mathrm{HQ}$, et al. Heparin-binding protein levels correlate with aggravation and multiorgan damage in severe COVID-19. ERJ Open Research 2021;7(1):00741-2020.

33. White D, MacDonald S, Bull T, et al. Heparin resistance in COVID-19 patients in the intensive care unit. Journal of thrombosis and thrombolysis 2020;50(2):287-291.

34. Fisher J, Linder A. Heparin-binding protein: a key player in the pathophysiology of organ dysfunction in sepsis. Journal of Internal Medicine 2017;281(6):562-574.

35. Jimenez D, Garcia-Sanchez A, Rali P, et al. Incidence of VTE and Bleeding Among Hospitalized Patients With Coronavirus Disease 2019: A Systematic Review and Metaanalysis. Chest 2021;159(3):1182-1196. 
medRxiv preprint doi: https://doi.org/10.1101/2021.05.13.21256846; this version posted May 17, 2021. The copyright holder for this preprint (which was not certified by peer review) is the author/funder, who has granted medRxiv a license to display the preprint in perpetuity.

\begin{tabular}{|c|c|c|}
\hline Characteristic & $\begin{array}{l}\text { Therapeutic-dose } \\
\text { anticoagulation } \\
(\mathrm{N}=1181)^{\mathrm{b}}\end{array}$ & $\begin{array}{l}\text { Usual care pharmacological } \\
\text { thromboprophylaxis } \\
(\mathrm{N}=1050)^{\mathrm{b}}\end{array}$ \\
\hline Age - year & $59.0(14.1)$ & $58.8(13.9)$ \\
\hline Male Sex - no. (\%) & $713 / 1181(60.4)$ & $597 / 1050(56.9)$ \\
\hline \multicolumn{3}{|l|}{ Race } \\
\hline White - no. (\%) & $622 / 994(62.6)$ & $564 / 845(66.7)$ \\
\hline Asian - no. (\%) & $41 / 994$ (4.1) & $43 / 845(5.1)$ \\
\hline Black - no. (\%) & 219/994 (22) & $162 / 845(19.2)$ \\
\hline First Nations/American Indian - no. (\%) & $118 / 965(12.2)$ & $82 / 819(10.0)$ \\
\hline Other - no. (\%) & $17 / 1109(1.5)$ & $16 / 968(1.7)$ \\
\hline Hispanic or Latino ethnicity - no. (\%) & $574 / 1004(57.2)$ & $537 / 879(61.1)$ \\
\hline \multirow[t]{2}{*}{ Body mass index, kg/m2 } & $29.8(26.3-34.7)$ & $30.3(26.7-34.9)$ \\
\hline & $\mathrm{N}=979$ & $\mathrm{~N}=860$ \\
\hline \multicolumn{3}{|l|}{ Pre-existing conditions } \\
\hline Hypertension - no. (\%) & $546 / 1023(53.4)$ & $447 / 892(50.1)$ \\
\hline Diabetes mellitus - no. (\%) & $352 / 1181(29.8)$ & $311 / 1049$ (29.6) \\
\hline Severe cardiovascular disease ${ }^{c}-$ no. (\%) & $123 / 1165(10.6)$ & $123 / 1165(10.6)$ \\
\hline Chronic kidney disease - no. (\%) & $83 / 1173(7.1)$ & $69 / 1037(6.7)$ \\
\hline Chronic respiratory disease $^{d}-$ no. (\%) & $249 / 1132(22)$ & $212 / 988(21.5)$ \\
\hline Immunosuppressive disease - no. (\%) & $105 / 1143(9.2)$ & $103 / 1005(10.2)$ \\
\hline \multicolumn{3}{|l|}{ Baseline treatments } \\
\hline Antiplatelet agent $\mathrm{e}^{\mathrm{e}}$ no. (\%) & $148 / 1140(13.0)$ & $111 / 1013(11.0)$ \\
\hline Remdesivir - no. (\%) & $428 / 1178(36.3)$ & $383 / 1048(36.5)$ \\
\hline Corticosteroids - no. (\%) & $479 / 791(60.6)$ & $415 / 656(63.3)$ \\
\hline Tocilizumab - no. (\%) & $6 / 1178(0.5)$ & $7 / 1048(0.7)$ \\
\hline \multicolumn{3}{|l|}{ Baseline respiratory support - n/N (\%) } \\
\hline None - no. (\%) & $156 / 1181(13.2)$ & $123 / 1050(11.7)$ \\
\hline Low flow nasal cannula/face mask - no. (\%) & $789 / 1181(66.8)$ & $696 / 1050(66.3)$ \\
\hline High flow nasal cannula - no. (\%) & $25 / 1181(2.1)$ & $28 / 1050(2.7)$ \\
\hline Non-invasive mechanical ventilation - no. (\%) & $21 / 1181(1.8)$ & $24 / 1050(2.3)$ \\
\hline Unspecified $^{f}-$ no. $(\%)$ & $190 / 1181(16.1)$ & $179 / 1050(17.1)$ \\
\hline \multicolumn{3}{|l|}{ Laboratory values } \\
\hline D-dimer relative to site upper limit of & $1.6(0.9-2.6)$ & $1.5(1-2.7)$ \\
\hline normal & $N=900$ & $N=779$ \\
\hline \multirow[t]{2}{*}{ Platelets $\times 10^{9} / \mathrm{L}$} & $221(171-290)$ & 218 (172.5-289) \\
\hline & $N=1160$ & $N=1031$ \\
\hline \multirow[t]{2}{*}{ Lymphocytes $\times 10^{9} / \mathrm{L}$} & $0.9(0.7-1.3)$ & $1(0.7-1.4)$ \\
\hline & $N=1032$ & $N=908$ \\
\hline \multirow[t]{2}{*}{ Creatinine (mg/dL) } & $0.9(0.7-1.1)$ & $0.9(0.7-1.1)$ \\
\hline & $N=1144$ & $N=1012$ \\
\hline \multicolumn{3}{|l|}{ Platform of enrollment ${ }^{\mathrm{g}}$} \\
\hline ATTACC ${ }^{h}-$ no. (\%) & $650 / 1181(55.0)$ & $509 / 1050(48.5)$ \\
\hline ACTIV-4a-no. (\%) & $387 / 1181(32.8)$ & $392 / 1050(37.3)$ \\
\hline REMAP-CAP - no. (\%) & $144 / 1181(12.2)$ & $149 / 1050(14.2)$ \\
\hline Country of enrollment & & \\
\hline
\end{tabular}


medRxiv preprint doi: https://doi.org/10.1101/2021.05.13.21256846; this version posted May 17, 2021. The copyright holder for this preprint (which was not certified by peer review) is the author/funder, who has granted medRxiv a license to display the preprint in perpetuity. All rights reserved. No reuse allowed without permission.

\begin{tabular}{|lcc|}
\hline United Kingdom - no. (\%) & $95 / 1181(8)$ & $103 / 1049(9.8)$ \\
United States - no. (\%) & $573 / 1181(48.5)$ & $506 / 1049(48.2)$ \\
Canada - no. (\%) & $102 / 1181(8.6)$ & $83 / 1049(7.9)$ \\
Brazil - no. (\%) & $234 / 1181(19.8)$ & $209 / 1049(19.9)$ \\
Otheri - no. (\%) & $177 / 1181(15)$ & $148 / 1049(14.1)$ \\
\hline
\end{tabular}

Median [IQR] or proportions. Abbreviations: No. = number.

Footnotes:

a. all moderate severity participants; Supplementary Appendix Table S2 for baseline characteristics stratified by Ddimer group;

b. Unequal denominators due to response-adaptive randomization

c. defined in REMAP-CAP as a baseline history of New York Heart Association class IV symptoms; defined in ACTIV4a and ATTACC as a baseline history of heart failure, myocardial Infarction, coronary artery disease, peripheral arterial disease, or cerebrovascular disease (stroke or transient ischemic attack);

d. defined as a baseline history of asthma, chronic obstructive pulmonary disease, bronchiectasis, interstitial lung disease, primary lung cancer, pulmonary hypertension, active tuberculosis, or through the receipt of home oxygen therapy;

e. not included in this summary are 74 participants co-enrolled in the REMAP-CAP Antiplatelet Domain (39 in the therapeutic anticoagulation arm and 35 in the usual care thromboprophylaxis arm);

f. in REMAP-CAP, levels of oxygen support, including no support, below high flow nasal cannula were not differentiated;

g. imbalanced randomization due to implementation of response-adaptive randomization in ATTACC on December 15, 2020;

h. 215 patients enrolled by the ATTACC platform were funded by the ACTIV4a platform from the National Heart Lung and Blood Institute of the $\mathrm{NIH}$;

i. other participating countries included: Mexico, Nepal, Australia, Netherlands, and Spain. 
medRxiv preprint doi: https://doi.org/10.1101/2021.05.13.21256846; this version posted May 17, 2021. The copyright holder for this preprint (which was not certified by peer review) is the author/funder, who has granted medRxiv a license to display the preprint in perpetuity. All rights reserved. No reuse allowed without permission.

\section{Figure Legends}

Figure 1. Screening, enrollment, randomization, and inclusion in analysis. Footnotes: a. sites used varying screening and documentation practices during the pandemic to identify eligible patients (Protocol Appendix); as reported, 3799 assessed for eligibility in ACTIV-4a, 7202 assessed for eligibility in ATTACC, and 2372 assessed for eligibility in REMAP-CAP; $\mathbf{b}$. potentially used for covariate adjustment and dynamic borrowing; c. may be imbalanced due to response adaptive randomization; $\mathbf{d}$. reasons (number of participants) for non-inclusion of Moderate severity participants assigned to receive therapeutic anticoagulation in the modified intention to treat primary analysis population included: withdrawal of consent (9), SARS-CoV-2 not confirmed (9), and outcome not available (1); e. reasons (number of participants) for noninclusion of Moderate severity participants assigned to receive usual care pharmacological thromboprophylaxis in the modified intention to treat primary analysis population included: withdrawal of consent (2), SARS-CoV-2 not confirmed (3), and outcome not available (2).

Figure 2. Organ support-free days to day 21. Upper panel) the cumulative proportion (y-axis) for each intervention group along the ordinal scale ( $x$-axis). The ordinal scale ranges from -1 (inhospital death; the worst possible outcome) through 0 to 21 (among survivors, the numbers of days alive without organ support; intermediate outcomes), to 22 (survival to hospital discharge without receipt of organ support; the best possible outcome). The height of each curve at any point, for example, at day $=10$, indicates the proportion of participants with organ support-free days (OSFD) of 10 or lower (i.e., 10 or worse). The difference in height of the two curves at any point represents the difference in the cumulative probability of having a value for OSFDs less than or equal to that point on the x-axis. Lower panel) Organ support-free days are shown as horizontally stacked proportions by intervention group, with possible outcomes as: in-hospital death with or without the receipt of organ support (dark red; the worst possible outcome, corresponding to an ordinal scale score of -1); survival, requiring ICU-level organ support (red to blue gradient shading based on number of days alive without organ support; intermediate outcomes, corresponding to an ordinal scale scores of 0-21); and survival to hospital discharge, without requiring ICU-level organ support (dark blue; the best possible outcome, corresponding to an ordinal scale score of 22). The median adjusted proportional odds ratio for therapeutic dose vs. thromboprophylaxsis among all moderate severity participants in the modified intention-to-treat analysis was 1.29 (95\% credible interval 1.04 to 1.61; posterior probability of superiority 99.0\%).

Figure 3. Primary and secondary outcomes. Median adjusted proportional odds ratios and $95 \%$ credible intervals are shown, along with the corresponding probabilities for superiority (adjusted odds ratio $>1.0$ ), the control event proportion, and the mean adjusted improvement in absolute risk. Forest plots are shown such that values $>1.0$ favor therapeutic heparin and values $<1.0$ favor usual care pharmacological thromboprophylaxis. The High D-dimer group is defined as moderate severity participants with baseline D-dimer $\geq 2$ times local upper limit of normal for assay, the Low D-dimer group as moderate severity participants with baseline D- 
medRxiv preprint doi: https://doi.org/10.1101/2021.05.13.21256846; this version posted May 17, 2021. The copyright holder for this preprint (which was not certified by peer review) is the author/funder, who has granted medRxiv a license to display the preprint in perpetuity. All rights reserved. No reuse allowed without permission.

dimer $<2$ times local upper limit of normal for assay, and the baseline Unknown D-Dimer defined as moderate severity participants without available baseline D-dimer. Additional secondary endpoints are reported in Figure 4 and Supplementary Appendix Table S5. Abbreviations: $\mathrm{Crl}=$ credible interval. Footnotes: a. effect estimates are adjusted for age, sex, site, D-dimer group, and time epoch, and are computed so that a value greater than 1 indicates benefit from therapeutic anticoagulation; $\mathbf{b}$. calculated from the adjusted treatment effect and control event frequency; c. the primary analysis includes 630 High D-dimer moderate severity participants, 1075 Low D-dimer moderate severity participants, and 514 Unknown D-dimer moderate severity participants; the primary analysis uses dynamic borrowing across illness severity and D-dimer groups, whereby observations from one group are used to inform treatment effect estimation in other groups where effect is observed to be similar (results from a sensitivity analysis assuming independent treatment effects between D-dimer-defined groups are shown in Supplementary Appendix Table S5); treatment effects also reported for the overall moderate severity cohort $(n=2219)$ assuming a single treatment effect irrespective of $D$ dimer; $\mathbf{d}$. includes dynamic borrowing between D-dimer groups as derives from the primary model; other secondary outcomes do not employ dynamic borrowing; e. similar results were obtained from a time-to-event model of survival through 28 days: adjusted hazard ratio of 1.20 (95\% Crl, 0.88-1.61; posterior probability of superiority $87.8 \%$ ); f. dichotomous endpoint; similar results obtained following the exclusion of 52 participants receiving organ support at baseline (median adjusted odds ratio 1.30, 95\% Crl 1.06-1.62; posterior probability of superiority 99.3\%); g. ordinal outcome with death as the worst possible outcome.

Figure 4. Effect of therapeutic anticoagulation on mortality, organ and respiratory support, in the overall moderate severity cohort. Unadjusted proportions are shown by treatment group. The posterior probability of superiority of therapeutic anticoagulation with heparin in comparison to usual care thromboprophylaxis is shown for the combined probabilities of death and receipt of either organ support, or the subsets of mechanical respiratory support (noninvasive or invasive mechanical ventilation), or intubation. Abbreviations: IV = invasive ventilation; NIV = non-invasive ventilation; $\mathrm{Pr}=$ probability. Footnote: Models analyzed as follows: survival without organ support through 28 days (dichotomous outcome); mechanical respiratory support-free days (ordinal outcome based on days free of support, with in-hospital death assigned as 0 ) through 28 days; and survival free of invasive mechanical ventilation through 28 days (ordinal, death as the worse outcome). 
medRxiv preprint doi: https://doi.org/10.1101/2021.05.13.21256846; this version posted May 17, 2021. The copyright holder for this preprint (which was not certified by peer review) is the author/funder, who has granted medRxiv a license to display the preprint in perpetuity. All rights reserved. No reuse allowed without permission.

\section{Figure 1}

1190 assigned to receive therapeutic-dose anticoagulation with heparin ${ }^{c, d}$

\section{High D-dimer group}

343 included in baseline analysis 339 Included in primary analysis

581 Low D-dimer group

576 included in baseline analysis $\mathbf{5 7 0}$ Included in primary analysis

265 Unknown D-dimer group

262 included in baseline analysis 262 Included in primary analysis
9890 Ineligible

2111 Another indication for therapeutic anticoagulation

729 Risk factor for bleeding

7050 Other

32 Provided consent but not randomized

16 No longer met inclusion criteria

8 Developed an exclusion criterion

8 Consent withdrawn before randomization

1207 Baseline Severe state (ICU-level of care) ${ }^{b}$

2245 Baseline Moderate state

hospitalized, not initially ICU-level of care)

Randomized to

receive therapeutic-

dose anticoagulation 
medRxiv preprint doi: https://doi.org/10.1101/2021.05.13.21256846; this version posted May 17, 2021. The copyright holder for this preprint (which was not certified by peer review) is the author/funder, who has granted medRxiv a license to display the preprint in perpetuity.

All rights reserved. No reuse allowed without permission.

\section{Figure 2}

\section{Proportion}

Therapeutic dose anticoagulation

Pharmacological thromboprophylaxis

\section{Cumulative proportion}

— Therapeutic dose anticoagulation

— Pharmacological thromboprophylaxis

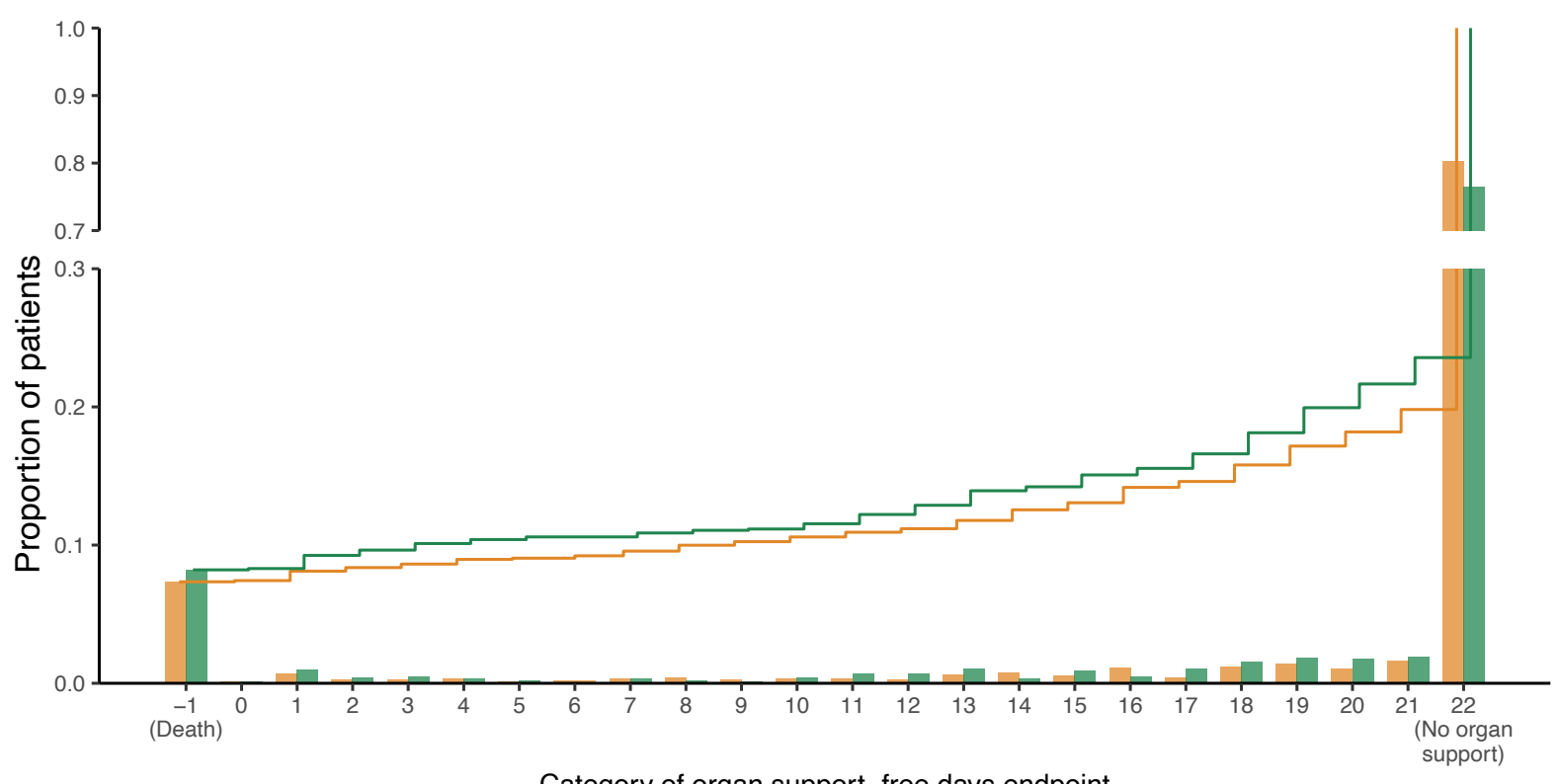

Category of organ support-free days endpoint

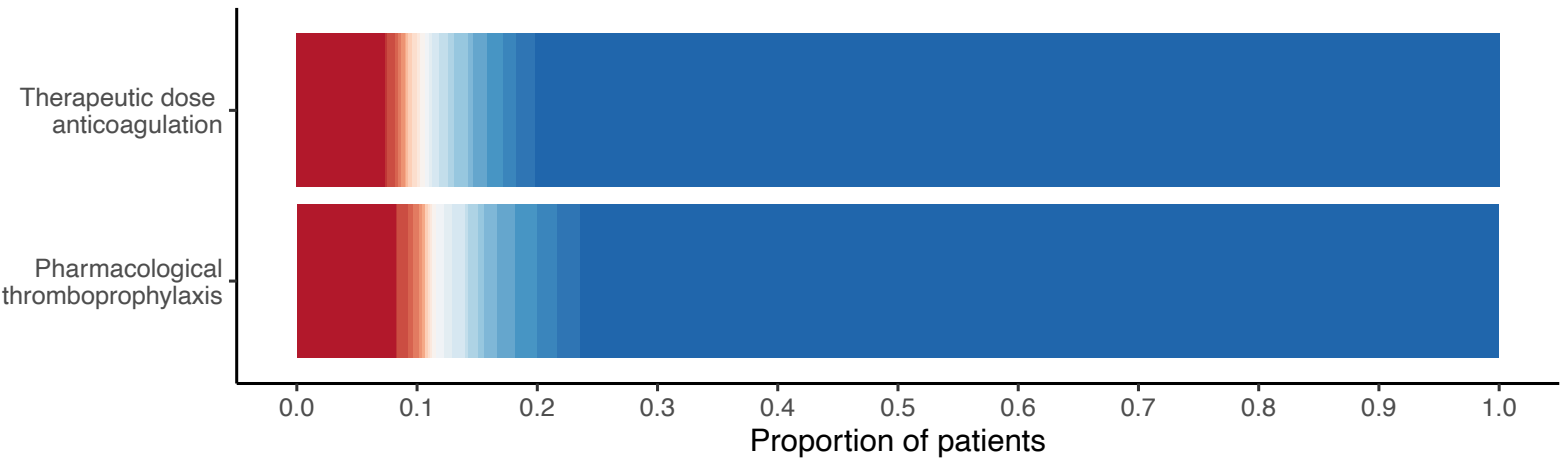

OSFD 


\section{Figure 3}

\section{Adjusted odds ratio $(95 \% \mathrm{Crl})^{\mathrm{a}}$}

- Organ support freedays (primary endpoint) ${ }^{c}$

Unknown D-dimer

- Survival to hospital discharge (secondary endpoint) ${ }^{\text {d, }}$

$$
\text { All moderate participants }
$$

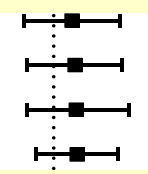

Survival without organ supp
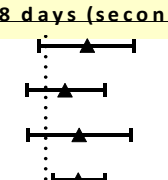

:

\section{s (secondary endpoint) ${ }^{8}$}

- Survival without intubation

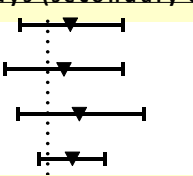

$$
\begin{aligned}
& 1.14 \text { (0.71 to } 1.84) \\
& 1.20(0.80 \text { to } 1.83) \\
& 1.29 \text { (0.79 to } 2.18)
\end{aligned}
$$

All moderate participants -

1.22 (0.93 to 1.59$)$

- Survival to hospital discharge without major thrombosis (secondary endpoint)

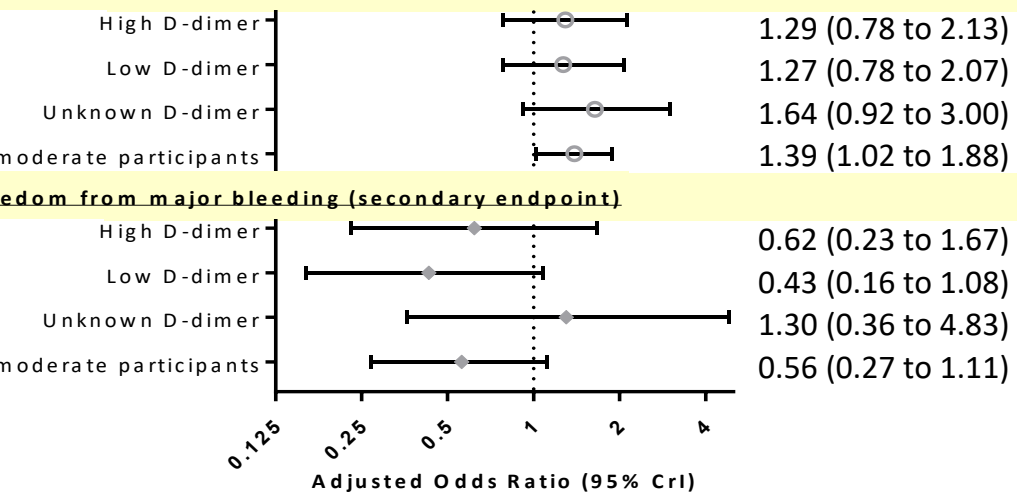

Favors usual care Favors therapeutic anticoagulation
Posterior probability

of superiority

$97.3 \%$

$92.9 \%$

$97.3 \%$

$99.0 \%$

$78.6 \%$

$81.7 \%$

$82.1 \%$

$87.1 \%$

$96.0 \%$

$89.4 \%$

$90.2 \%$

$99.1 \%$

$71.3 \%$

$80.9 \%$

$84.3 \%$

$92.2 \%$

$84.1 \%$

$83.0 \%$

$95.2 \%$

$98.0 \%$

$17.7 \%$

$3.7 \%$

$65.5 \%$

$4.8 \%$
Control event proportion

-
-
-

260/291 (89.3)

$477 / 505$ (94.5)

$225 / 252(89.3)$

$962 / 1048$ (91.8)

205/290 (70.7)

396/503 (78.7)

$188 / 253(74.3)$

$789 / 1046$ (75.4)

$253 / 292$ (86.6)

$457 / 505$ (90.5)

$213 / 253(84.2)$

$923 / 1050$ (87.9)

253/292 (86.6)

$473 / 505$ (93.7)

216/249 (86.7)

942/1046 (90.1)

288/292 (98.6)

$503 / 505$ (99.6)

247/250 (98.8)

1038/1047 (99.1)
Adjusted improvement in absolute risk $(95 \% \mathrm{CrI})^{\text {b }}$

\author{
$1.3 \%(-2.5,4.2)$ \\ $0.8 \%(-1.2,2.3)$ \\ $1.6 \%(-2.2,4.6)$ \\ $1.3 \%(-1.1,3.2)$ \\ $6.5 \%(-0.9,12.3)$ \\ $3.1 \%(-1.0,7.2)$ \\ $6.0 \%(-2.1,12.2)$ \\ $4.5 \%(0.9,7.7)$ \\ $1.4 \%(-4.5,5.6)$ \\ $1.5 \%(-2.1,4.1)$ \\ $3.1 \%(-3.4,7.9)$ \\ $2.0 \%(-0.8,4.1)$ \\ $2.7 \%(-3.2,6.6)$ \\ $1.3 \%(-1.6,3.2)$ \\ $4.7 \%(-1.0,8.4)$ \\ $2.6 \%(0.2,4.4)$ \\ $-0.8 \%(-4.4,0.6)$ \\ $-0.5 \%(-2.0,0.0)$ \\ $0.3 \%(-2.1,0.9)$ \\ $-0.7 \%(-2.4,0.1)$
}




\section{Figure 4}
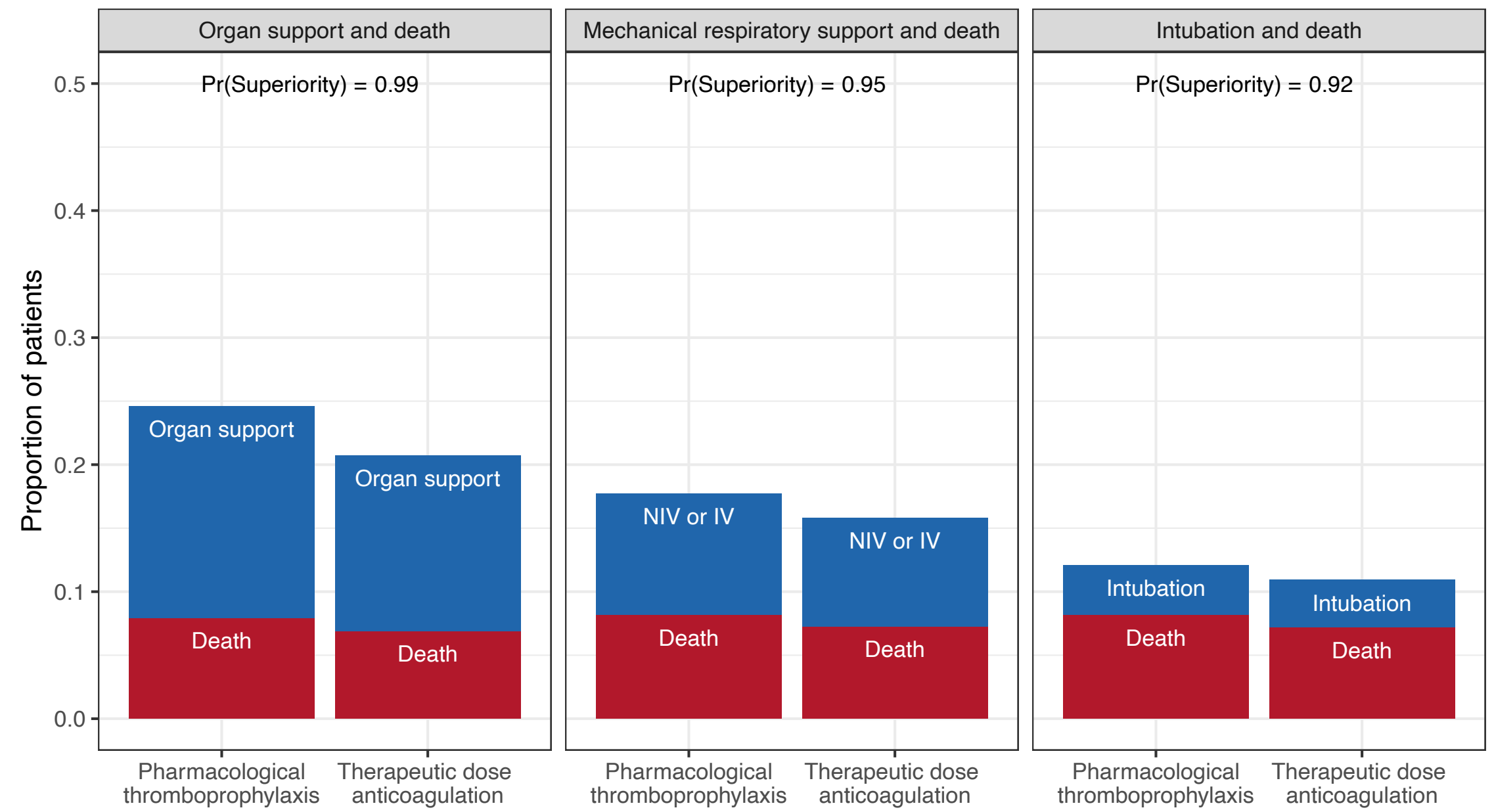
medRxiv preprint doi: https://doi.org/10.1101/2021.05.13.21256846; this version posted May 17, 2021. The copyright holder for this preprint (which was not certified by peer review) is the author/funder, who has granted medRxiv a license to display the preprint in perpetuity.

\section{Authors:}

\section{Executive Writing Committee:}

Patrick R. Lawler, M.D., M.P.H. ${ }^{* 1,2}$, Ewan C. Goligher, M.D., Ph.D. ${ }^{* 2,3}$, Jeffrey S. Berger, M.D.*4, Matthew D. Neal, M.D. ${ }^{* 5,6}$, Bryan J. McVerry, M.D*5,6, Jose C. Nicolau, M.D., Ph.D.7, Michelle N. Gong, M.D. ${ }^{8,9}$, Marc Carrier, M.D., M.Sc. ${ }^{10,11}$, Robert S. Rosenson, M.D. ${ }^{12,13}$, Harmony R. Reynolds, M.D. ${ }^{4}$, Alexis F. Turgeon, M.D., M.Sc. ${ }^{14,15}$, Jorge Escobedo, M.D. ${ }^{16}$, David T. Huang, M.D., M.P.H. ${ }^{5}$, Charlotte Ann Bradbury, M.B., Ch.B., Ph.D. ${ }^{17,18}$, Brett L. Houston, M.D. ${ }^{19,20}$, Lucy Z. Kornblith, M.D. ${ }^{21}$, Anand Kumar, M.D. ${ }^{19}$, Susan R. Kahn, M.D., M.Sc. ${ }^{22}$, Mary Cushman, M.D., M.Sc. ${ }^{23}$, Zoe McQuilten, Ph.D. ${ }^{24}$, Arthur S. Slutsky, M.D. ${ }^{2,25}$, Keri S. Kim, Pharm. D. ${ }^{26}$, Anthony C. Gordon, M.B.B.S., M.D. ${ }^{27,28}$, Bridget-Anne Kirwan, Ph.D. ${ }^{29,30}$, Maria M. Brooks, Ph.D. ${ }^{5}$, Alisa M. Higgins, Ph.D. ${ }^{24}$, Roger J. Lewis, M.D., Ph.D. ${ }^{31,32}$, Elizabeth Lorenzi, Ph.D. ${ }^{31}$, Scott M. Berry, Ph.D. ${ }^{31}$, Lindsay R. Berry, Ph.D. ${ }^{31}$, Derek C. Angus, M.D., M.P.H. ${ }^{5,6}$, Colin J. McArthur, M.B., Ch.B. ${ }^{* * 24,33,34}$, Steven A. Webb, M.P.H., Ph.D. ${ }^{* * 24,35}$, Michael E. Farkouh, M.D., M.Sc.**1,2, Judith S. Hochman, M.D., M.A. ${ }^{* * 4}$, Ryan Zarychanski, M.D., M.Sc. ${ }^{* * 19,20}$.

$*, * *$ denotes equal contribution

Block Writing Committee: (In alphabetical order)

Aaron W. Aday, M.D. ${ }^{36}$, Farah Al-Beidh, Ph.D. ${ }^{27}$, Djillali Annane, M.D., Ph.D. ${ }^{37}$, Yaseen M. Arabi, M.D. ${ }^{38,39}$, Diptesh Aryal, M.D. ${ }^{40,41}$, Lisa Baumann Kreuziger, M.D. ${ }^{42}$, Abi Beane, Ph.D. ${ }^{43,44}$, Zahra Bhimani, M.P.H. ${ }^{25}$, Shailesh Bihari, Ph.D. ${ }^{45}$, Henny H. Billett, M.D., M.Sc. ${ }^{8,9}$, Lindsay Bond ${ }^{46}$, Marc Bonten, Ph.D. ${ }^{47}$, Frank Brunkhorst ${ }^{48}$, Meredith Buxton, Ph.D. ${ }^{49}$, Adrian BuzgauError! Bookmark not defined., Lana A. Castellucci, M.D., M.Sc. ${ }^{10,50}$, Sweta Chekuri, M.D. ${ }^{8}$, Jen-Ting Chen, M.D., M.S. ${ }^{8}$, Allen C. Cheng, Ph.D. ${ }^{51,52}$, Tamta Chkhikvadze, M.D. ${ }^{4,53}$, Benjamin Coiffard, M.D., M.Sc. ${ }^{54}$, Todd W. Costantini, M.D. ${ }^{55}$, Sophie de Brouwer, Ph.D. ${ }^{32}$, Lennie P. G. Derde, M.D., Ph.D. ${ }^{47}$, Michelle A. Detry, Ph.D. ${ }^{31}$, Abhijit Duggal, M.D., M.P.H., M.Sc. ${ }^{56}$, Vladimír Džavík, M.D. ${ }^{1,2}$, Mark B. Effron, M.D. ${ }^{57}$, Lise J. Estcourt, M.B.B.Chir., D.Phil. ${ }^{42,58}$, Brendan M. Everett, M.D., M.P.H. ${ }^{59}$, Dean A. Fergusson, Ph.D. ${ }^{10,50}$, Mark Fitzgerald, Ph.D. ${ }^{31}$, Robert A. Fowler, M.D. ${ }^{2}$, Jean Philippe Galanaud, M.D. ${ }^{1,60}$, Benjamin T. Galen, M.D. ${ }^{9}$, Sheetal Gandotra, M.D. ${ }^{61}$, Sebastian García-Madrona, M.D. ${ }^{62}$, Timothy D. Girard, M.D. ${ }^{63}$, Lucas C. Godoy, M.D. ${ }^{1,2,7}$, Andrew L. Goodman, M.D. ${ }^{64}$, Herman Goossens, M.D. ${ }^{65}$, Cameron Green, M.Sc. ${ }^{24}$, Yonatan Y. Greenstein, M.D. ${ }^{66}$, Peter L. Gross, M.D., M.Sc. ${ }^{67,68}$, Naomi M. Hamburg, M.D., M.Sc. ${ }^{69,70}$, Rashan Haniffa, Ph.D. ${ }^{71,72}$, George Hanna, M.D. ${ }^{1,2}$, Nicholas Hanna, M.D. ${ }^{73,74}$, Sheila M. Hegde, M.D., M.P.H. ${ }^{75}$, Carolyn M. Hendrickson, M.D. ${ }^{21}$, R. Duncan Hite, M.D. ${ }^{78}$, Alexander A. Hindenburg, M.D. ${ }^{76}$, Aluko A. Hope, M.D., M.S.C.E. ${ }^{9}$, James M. Horowitz, M.D. ${ }^{53}$, Christopher M. Horvat, M.D., M.H.A. ${ }^{77}$, Kristin Hudock, M.D., M.S.T.R. ${ }^{78}$, Beverley J. Hunt, O.B.E. ${ }^{79}$, Mansoor Husain, M.D. ${ }^{2,3}$, Robert C. Hyzy, M.D. ${ }^{80}$, Vivek N. Iyer, M.D., M.P.H. ${ }^{81}$, Jeffrey R. Jacobson, M.D. ${ }^{26}$, Devachandran Jayakumar, M.D. ${ }^{82}$, Norma M. Keller, M.D. ${ }^{4,83}$, Akram Khan, M.D. ${ }^{84}$, Yuri Kim, M.D., Ph.D. ${ }^{59}$, Andrei L. Kindzelski,M.D., Ph.D. ${ }^{85}$, Andrew J. King, Ph.D. ${ }^{5}$, M. Margaret Knudson, M.D. ${ }^{21}$, Aaron E. Kornblith, M.D. ${ }^{21}$, Vidya Krishnan, M.D., M.H.S. ${ }^{86}$, Matthew E. Kutcher, M.D., M.S. ${ }^{87}$, Michael A. Laffan, D.M. ${ }^{27}$, Francois Lamontagne, M.D. ${ }^{88}$, Grégoire Le Gal, M.D., Ph.D. ${ }^{10,11}$, Christine M. Leeper, M.D., M.Sc. ${ }^{5}$, Eric S. Leifer, Ph.D. ${ }^{84}$, George Lim, M.D. ${ }^{89}$, Felipe Gallego Lima, M.D. ${ }^{7}$, Kelsey Linstrum, M.S. ${ }^{5,6}$, Edward Litton, Ph.D. ${ }^{35,90}$, Jose Lopez-Sendon, Ph.D. ${ }^{91}$, Jose Luis LopezSendon Moreno, M.D. ${ }^{62}$, Sylvain A. Lother, M.D.Error! Bookmark not defined., Saurabh 
medRxiv preprint doi: https://doi.org/10.1101/2021.05.13.21256846; this version posted May 17, 2021. The copyright holder for this preprint (which was not certified by peer review) is the author/funder, who has granted medRxiv a license to display the preprint in perpetuity.

Malhotra, M.D., M.P.H. ${ }^{92,93}$, Miguel Marcos, Ph.D. ${ }^{94}$, Andréa Saud Marinez, Pharm.D., M.Sc. ${ }^{95}$, John C. Marshall, M.D. ${ }^{25}$, Nicole Marten, R.N. ${ }^{96}$, Michael A. Matthay, M.D. ${ }^{21}$, Daniel F. McAuley, M.D. ${ }^{97,98}$, Emily G. McDonald, M.D., M.Sc. ${ }^{22}$, Anna McGlothlin, Ph.D. ${ }^{31}$, Shay P. McGuinness, M.B., Ch.B. ${ }^{24,99}$, Saskia Middeldorp, M.D., Ph.D. ${ }^{100}$, Stephanie K. Montgomery, M.Sc. ${ }^{5,6}$, Steven C. Moore, M.D. ${ }^{101}$, Raquel Morillo Guerrero, Ph.D. ${ }^{62}$, Paul R. Mouncey, M.Sc. ${ }^{102}$, Srinivas Murthy, M.D. ${ }^{103}$, Girish B. Nair, M.D., M.S. ${ }^{104,105}$, Rahul Nair, M.D. ${ }^{8}$, Alistair D. Nichol, M.B., Ph.D. ${ }^{24,52,106}$, Brenda Nunez-Garcia, B.A. ${ }^{21}$, Ambarish Pandey, M.D. ${ }^{107}$, Pauline K. Park, M.D. ${ }^{80}$, Rachael L. Parke, Ph.D. ${ }^{99,108}$, Jane C. Parker, B.N. ${ }^{24}$, Sam Parnia, M.D., Ph.D. ${ }^{4}$, Jonathan D. Paul, M.D. ${ }^{109}$, Yessica Sara Pérez González, M.D. ${ }^{16}$, Mauricio Pompilio, Ph.D. ${ }^{110,111}$, Matthew E. Prekker, M.D., M.P.H. ${ }^{112}$, John G. Quigley, M.D. ${ }^{26}$, Natalia S. Rost, M.D. ${ }^{113,114}$, Kathryn Rowan, Ph.D. ${ }^{102}$, Fernanda O. Santos, M.D. ${ }^{115}$, Marlene Santos, M.D., M.Sc. ${ }^{25}$, Mayler Olombrada Santos, M.Sc. ${ }^{116}$, Lewis Satterwhite, M.D. ${ }^{117}$, Christina T. Saunders, Ph.D. ${ }^{31}$, Roger E.G. Schutgens, M.D., Ph.D. ${ }^{47}$, Christopher W. Seymour, M.D., M.Sc.Error! Bookmark not defined., Deborah M. Siegal, M.D., M.Sc. ${ }^{10,50}$, Delcio G. Silva Junior, M.Med. ${ }^{118,119}$, Manu Shankar-Hari, Ph.D. ${ }^{120,121}$, John P. Sheehan, M.D. ${ }^{122}$, Aneesh B. Singhal, M.D. ${ }^{113,114}$, Dayna Solvason ${ }^{19}$, Simon J. Stanworth, F.R.C.P., D.Phil. ${ }^{43,58}$, Tobias Tritschler, M.D., M.Sc. ${ }^{123}$, Anne M. Turner, M.P.H. ${ }^{34}$, Wilma van Bentum-Puijk, M.Sc. ${ }^{47}$, Frank L. van de Veerdonk, M.D., Ph.D. ${ }^{100}$, Sean van Diepen, M.D., M.Sc. ${ }^{124}$, Gloria Vazquez-Grande, M.D., M.Sc. ${ }^{19}$, Lana Wahid, M.D. ${ }^{125}$, Vanessa Wareham, H.B.Sc. ${ }^{46}$, Bryan J. Wells, M.D. ${ }^{126}$, R. Jay Widmer, M.D., Ph.D. ${ }^{127}$, Jennifer G. Wilson, M.D. ${ }^{128}$, Eugene Yuriditsky, M.D. ${ }^{53}$, Fernando G. Zampieri, M.D., Ph.D. ${ }^{129}$. 
medRxiv preprint doi: https://doi.org/10.1101/2021.05.13.21256846; this version posted May 17, 2021. The copyright holder for this preprint (which was not certified by peer review) is the author/funder, who has granted medRxiv a license to display the preprint in perpetuity.

All rights reserved. No reuse allowed without permission.

1 Peter Munk Cardiac Centre at University Health Network, Toronto, Canada

2 University of Toronto, Toronto, Canada

3 University Health Network, Toronto, Canada

4 NYU Grossman School of Medicine, New York City, United States

5 University of Pittsburgh, Pittsburgh, United States

6 UPMC, Pittsburgh, United States

7 Instituto do Coração (InCor), Hospital das Clínicas HCFMUSP, Universidade de São Paulo, São Paulo, Brazil

8 Montefiore Medical Center, Bronx, United States

9 Albert Einstein College of Medicine, Bronx, United States

10 Ottawa Hospital Research Institute, Ottawa, Canada

11 Institut du Savoir Montfort, Ottawa, Canada

12 Icahn School of Medicine at Mount Sinai, New York City, United States

13 Mount Sinai Heart, New York City, United States

14 Université Laval, Québec City, Canada

15 CHU de Québec - Université Laval Research Center, Québec City, Canada

16 Instituto Mexicano del Seguro Social, Mexico City, Mexico

17 University of Bristol, Bristol, United Kingdom

18 University Hospitals Bristol and Weston NHS Foundation Trust, Bristol, United Kingdom

19 University of Manitoba, Winnipeg, Canada

20 CancerCare Manitoba, Winnipeg, Canada

21 Zuckerberg San Francisco General Hospital/University of California, San Francisco, United States

22 McGill University, Montreal, Canada

23 Larner College of Medicine at the University of Vermont, Burlington, United States

24 Australian and New Zealand Intensive Care Research Centre, Monash University, Melbourne, Australia

25 St. Michael's Hospital Unity Health, Toronto, Canada

26 University of Illinois, Chicago, United States

27 Imperial College London, London, United Kingdom

28 Imperial College Healthcare NHS Trust, St. Mary's Hospital, London, United Kingdom

29 SOCAR Research SA, Nyon, Switzerland

30 London School of Hygiene and Tropical Medicine, London, UK

31 Berry Consultants, LLC, Austin, United States

32 Harbor-UCLA Medical Center, Torrance, United States

33 Auckland City Hospital, Auckland, New Zealand

34 Medical Research Institute of New Zealand, Wellington, New Zealand

35 St John of God Hospital, Subiaco, Australia

36 Vanderbilt University Medical Center, Nashville, United States

37 Fédération Hospitalo Universitaire, Raymond Poincaré Hospital, UVSQ, Garches, France

38 King Saud bin Abdulaziz University for Health Sciences, Riyadh, Kingdom of Saudi Arabia 
medRxiv preprint doi: https://doi.org/10.1101/2021.05.13.21256846; this version posted May 17, 2021. The copyright holder for this preprint (which was not certified by peer review) is the author/funder, who has granted medRxiv a license to display the preprint in perpetuity.

All rights reserved. No reuse allowed without permission.

39 King Abdullah International Medical Research Center, Riyadh, Kingdom of Saudi Arabia

40 Nepal Mediciti Hospital, Lalitpur, Nepal

41 Nepal Intensive Care Research Foundation, Kathmandu, Nepal

42 Versiti Blood Research Institute, Milwaukee, United States

43 Oxford University, Oxford, United Kingdom

44 NICS-MORU, Colombo, Sri Lanka

45 Flinders University, Bedford Park, Australia

46 Ozmosis Research Inc., Toronto, Ontario

47 University Medical Center Utrecht, Utrecht University, Utrecht, The Netherlands

48 Jena University Hospital, Jena, Germany

49 Global Coalition for Adaptive Research, Los Angeles, United States

50 University of Ottawa, Ottawa, Canada

51 Monash University, Melbourne, Australia

52 Alfred Health, Melbourne, Australia

53 NYU Langone Health, NYU Langone Hospital, New York City, United States

54 Aix-Marseille University, Marseille, France

55 University of California San Diego School of Medicine, San Diego, United States

56 Cleveland Clinic, Cleveland, Ohio

57 Ochsner Medical Center, University of Queensland-Ochsner Clinical School, New Orleans, United States

58 NHS Blood and Transplant, Oxford, United Kingdom

59 Harvard Medical School and Brigham and Women's Hospital, Boston, United States

60 Sunnybrook Health Sciences Centre, Toronto, Canada

61 University of Alabama, Birmingham, United States

62 Hospital Ramón y Cajal (IRYCIS), Madrid, España

63 The Clinical Research, Investigation, and Systems Modeling of Acute Illness (CRISMA) Center, University of Pittsburgh, Pittsburgh, United States

64 TriStar Centennial Medical Center, Nashville, United States

65 University of Antwerp, Wilrijk, Belgium

66 Rutgers New Jersey Medical School, Newark, United States

67 McMaster University, Hamilton, Canada

68 Thrombosis and Atherosclerosis Research Institute, Hamilton, Canada

69 Boston University School of Medicine, Boston, United States

70 Boston Medical Center, Boston, United States

71 University of Oxford, Bangkok, Thailand

72 University College London Hospital, London, United Kingdom

73 Ascension St. John Heart and Vascular Center, Tulsa, United States

74 University of Oklahoma College of Medicine, Oklahoma City, United States

75 Brigham and Women's Hospital, Boston, United States

76 NYU Langone Long Island, Mineola, United States

77 UPMC Children's Hospital of Pittsburgh, Pittsburgh, United States

78 University of Cincinnati, Cincinnati, United States 
medRxiv preprint doi: https://doi.org/10.1101/2021.05.13.21256846; this version posted May 17, 2021. The copyright holder for this preprint (which was not certified by peer review) is the author/funder, who has granted medRxiv a license to display the preprint in perpetuity.

All rights reserved. No reuse allowed without permission.

79 Kings Healthcare Partners, London, United Kingdom

80 University of Michigan, Ann Arbor, United States

81 Mayo Clinic, Rochester, United States

82 Apollo Speciality Hospital - OMR, Chennai, India

83 Bellevue Hospital, New York City, United States

84 Oregon Health \& Science University, Portland, United States

85 National Heart Lung \& Blood Institute, NIH, Bethesda, United States

86 Case Western Reserve University, The Metro Health Medical Centre, Cleveland, United States

87 University of Mississippi Medical Center, Jackson, United States

88 Université de Sherbrooke, Sherbrooke, Canada

89 University of California Los Angeles, Los Angeles, United States

90 Fiona Stanley Hospital, Perth, Australia

91 IdiPaz Research Institute, Universidad Autonoma, Madrid, Spain

92 Cook County Health, Chicago, United States

93 Rush Medical College, Chicago, United States

94 University Hospital of Salamanca-University of Salamanca-IBSAL, Salamanca, Spain

95 Avanti Pesquisa Clínica, Sao Paulo, Brazil

96 St Boniface Hospital, Winnipeg, Canada

97 Queen's University Belfast, Belfast, Northern Ireland

98 Royal Victoria Hospital, Belfast, Northern Ireland

99 Auckland City Hospital, Auckland, New Zealand

100 Radboud University Medical Center, Nijmegen, The Netherlands

101 Penn State Hershey Medical Center, Emergency Medicine, Hershey, United States of America

102 Intensive Care National Audit \& Research Centre (ICNARC), London, United Kingdom

103 University of British Columbia, Vancouver, Canada

104 Beaumont Health, Royal Oak, United States

105 OUWB School of Medicine, Auburn Hills, United States

106 University College Dublin, Dublin, Ireland

107 University of Southwestern Medical Center, Dallas, United States

108 The University of Auckland, Auckland, New Zealand

109 University of Chicago, Chicago, United States

110 Hospital do Coração de Mato Grosso do Sul (HCMS), Campo Grande, Brazil

111 Federal University of Mato Grosso do Sul (UFMS), FAMED, Campo Grande, Brazil

112 Hennepin County Medical Center, Minneapolis, United States

113 Massachusetts General Hospital, Boston, United States

114 Harvard Medical School, Boston, United States

115 Hospital 9 de Julho, São Paulo, Brazil

116 INGOH, Clinical Research Center, Goiânia, Brazil.

117 University of Kansas School of Medicine, Kansas City, United States

118 Hospital Universitário Maria Aparecida Pedrossia, Campo Grande, Brazil 
119 Hospital Unimed Campo Grande, Campo Grande, Brazil

120 Guy's and St. Thomas' NHS Foundation Trust, London, United Kingdom

121 King's College London, London, United Kingdom

122 University of Wisconsin School of Medicine and Public Health, Madison, United States

123 Inselspital, Bern University Hospital, University of Bern, Switzerland

124 University of Alberta, Edmonton, Canada

125 Duke University Hospital, Durham, North Carolina

126 Emory University, Atlanta, United States

127 Baylor Scott and White Health, Temple, United States

128 Stanford University School of Medicine, Palo Alto, United States

129 HCor-Hospital do Coração, São Paulo, Brazil 